\title{
Flicker-induced retinal vessels dilatation in diabetic patients without clinically detectable diabetic retinopathy
}

\section{Analiza średnicy i reaktywności naczyń siatkówki u pacjentów z cukrzycą bez cech retinopatii}

\author{
Katarzyna Mozolewska-Piotrowska', Maria Nowacka², Monika Masiuk', Małgorzata Świder', \\ Katarzyna Babiak', Krzysztof Safranow ${ }^{3}$, Anna Machalińska' \\ 1 First Department of Ophthalmology, Pomeranian Medical University, Szczecin, Poland \\ Head: Professor Anna Machalińska, MD, PhD \\ 2 Department of Nephrology, Transplantology and Internal Medicine, Pomeranian Medical University, Szczecin, Poland \\ Head: Professor Kazimierz Ciechanowski, MD, PhD \\ 3 Department of Biochemistry and Medical Chemistry, Pomeranian Medical University, Szczecin, Poland \\ Head: Professor Dariusz Chlubek, MD, PhD
}

Ahstract:

Aim: Clinically detectable signs of diabetic retinopathy are preceded by endothelial dysfunction. Retinal microvasculature dynamics assessment using a dynamic vessel analyzer (DVA) may enable detection of neurovascular changes in vivo at the preclinical stage of diabetic complications and thus may help to recognize patients at increased risk of diabetic retinopathy. The aim of the study was to investigate the response of retinal vessels to flickering light in diabetic patients without clinically detectable diabetic retinopathy.

Materials and methods: Eighty eyes of 40 patients with type II diabetes and no clinically detectable diabetic retinopathy were enrolled in the study group. The control group consisted of 44 volunteers (88 eyes) without diabetes. The Dynamic Vessel Analyzer (DVA) was used to measure retinal vascular dilatation in response to flicker light stimulation.

Results: The AVR obtained by static vessel analysis was similar in both groups, whereas retinal vascular dilation after flicker stimulation in arterioles and veins was significantly reduced in the DM group (mean of $1.79 \%$ and $3.24 \%$, respectively) compared with the control group (mean of $2.86 \%$ and $4.07 \%$, respectively). DM was an independent factor associated with lower values of the flicker-light-induced vasodilation. A slight positive correlation was noted between the time of physical activity and better arterial response to flicker light in the diabetic group ( $R s=+0.34, p=0.03$ ).

Conclusions: 1. Retinal vessel reactivity to flicker light stimulation is reduced in diabetic patients with no clinically detectable signs of diabetic retinopathy. 2.DVA may be a valuable tool for early identification of patients at increased risk of diabetic retinopathy.

Key words: diabetic retinopathy, dynamic vessel analysis, retinal vessel reactivity, flicker-induced vessel dilation, DVA.

Abstrakt: $\quad$ Cel: Wystąpienie objawów klinicznych retinopatii cukrzycowej poprzedzają zmiany czynnościowe komórek śródbłonka naczyniowego. Pomiary dynamiki reakcji naczyń mikrokrążenia siatkówki przy użyciu dynamicznego analizatora naczyniowego (DVA) mogą umożliwić ocenę in vivo zmian w zakresie kompleksu nerwowo-naczyniowego w stadium przedklinicznym retinopatii cukrzycowej, a tym samym pomóc we wcześniejszym wyodrębnieniu grupy chorych z większym ryzykiem rozwoju lub/i progresji retinopatii. Celem badania była kompleksowa analiza naczyń siatkówki u pacjentów z cukrzycą, u których w badaniu okulistycznym nie stwierdzono cech retinopatii cukrzycowej.

Pacjenci i metodyka: Grupę badaną stanowito 40 pacjentów (80 oczu) z cukrzycą typu II bez cech retinopatii cukrzycowej widocznych w badaniu przedmiotowym, a grupę kontrolną 44 osoby (88 oczu) bez cukrzycy. Do pomiaru stopnia poszerzenia naczyń siatkówki w odpowiedzi na pobudzenie świattem migoczącym wykorzystano dynamiczny analizator naczyniowy (DVA)

Wyniki: Współczynnik tętniczo-żylny (AVR) był porównywalny w obu badanych grupach, natomiast reaktywność naczyń tętniczych i żylnych po stymulacji światlem była statystycznie istotnie niższa w grupie pacjentów z cukrzycą (odpowiednio śr. 1,79\% i 3,24\%) w porównaniu z grupą kontrolną (odpowiednio śr. 2,86\% i 4,07\%). Cukrzyca była niezależnym czynnikiem ryzyka słabszej reakcji naczyniowej po pobudzeniu światłem. U pacjentów z cukrzycą zaobserwowano dodatnią korelację pomiędzy ilością czasu poświęcanego przez pacjenta na aktywność fizyczną a lepszą odpowiedzią naczyń tętniczych (Rs $=+0.34, p=0.03$ ).

Wnioski: 1. Reaktywność naczyń po stymulacji siatkówki światłem migoczącym jest mniejsza u pacjentów z cukrzycą, u których nie stwierdzono cech retinopatii cukrzycowej w porównaniu z grupą kontrolną bez cukrzycy. 2. Badanie DVA może być cennym narzędziem umożliwiającym wczesne wyodrębnienie wśród chorych na cukrzycę pacjentów z wyższym ryzykiem rozwoju retinopatii cukrzycowej.

Slowa kluczowe: retinopatia cukrzycowa, dynamiczna analiza naczyniowa, reaktywność naczyń siatkówki, rozszerzenie naczyń indukowane świattem, DVA.

The authors declare no conflict of interest/ Autorzy zgłaszają brak konfliktu interesów w związku z publikowaną pracą 


\section{Introduction}

Diabetic retinopathy (DR) is the leading cause of significant visual impairment in patients with diabetes. Although the main risk factors of DR development and progression, such as glycemic and blood pressure control and diabetes duration, are well known, the risk of DR development in an individual patient remains very difficult to assess (1-3).

Structural damage to small blood vessels in diabetic retinopathy is preceded by endothelial dysfunction and neurodegenerative processes (4). Nitric oxide (NO) is one of the most important endothelium-derived vasodilators with decreased bioavailability in diabetic patients. There is evidence that NO-modulated neurovascular changes might be one of the pathways involved in DR development, mainly via reflecting retinal vascular endothelial function. NO also appears to be a mediator of the flicker-light-dependent vasodilation in the retinal vessels (5-7). Stimulating retina with flickering light increases retinal blood flow and arterial and venous diameters in heathy individuals, indicating a tight junction between vasoreactivity, blood flow and neural activity $(8,9)$. Reduced flicker-dependent vasodilation in patients with diabetic retinopathy may be a consequence of endothelial dysfunction and is thought to be an early indicator of endothelial dysfunction $(10,11)$. Measurements of this dynamic behavior of the retinal microvasculature by a dynamic vessel analyzer (DVA) may enable the assessment of neurovascular changes in vivo at the preclinical stage of diabetic pathology and, therefore, help to identify patients at increased risk of diabetic retinopathy development. Thus, the aim of the study was to investigate the response of retinal vessels to flickering light in diabetic patients without clinically detectable diabetic retinopathy.

\section{Patients and methods}

\section{Study group}

Eighty eyes of 40 patients with type II diabetes and no clinically detectable diabetic retinopathy were enrolled in the study group. The control group consisted of 44 age-matched volunteers (88 eyes) without DM. The exclusion criteria were: 1) concomitant eye disease, such as glaucoma, retinopathy, intraocular inflammatory diseases, recent ocular surgery, or advanced cataract; and 2) systemic or chronic vascular disease, i.e., autoimmune disease, cancer, ischemic heart or cerebral disease, aortic aneurysm and peripheral artery disease.

Written informed consent was obtained from all subjects before examination. The study protocol was approved by the Institutional Review Board of Pomeranian Medical University and adhered to the tenets of the Declaration of Helsinki (12).

All subjects from the study and control groups underwent a thorough ophthalmological examination of both eyes, including distant best-corrected visual acuity (DBCVA), intraocular pressure (IOP), anterior segment slit lamp examination and dilated fundus ophthalmoscopy with slit lamp biomicroscopy. Only patients with DBCVA better then 20/25 on the Snellen chart and no clinically detectable pathologies of the anterior segment and eye fundus were enrolled.

The following medical parameters were assessed in all participants from both the study and control groups: 1) total cholesterol (TCH); 2) low-density lipoprotein (LDL); 3) high-density li- poprotein (HDL); 4) triglycerides (TG); 5) cumulative pack years of smoking; 6) body mass index (BMI); and 7) waist-to-hip ratio (WHR). In the study group, the HbA1c level was additionally evaluated, and the duration of both diabetes and arterial hypertension (years) was noted. The systemic mean arterial pressure (MAP) was calculated as follows: MAP $=$ diastolic $B P=1 / 3 \times$ (systolic BP - diastolic BP) mmHg.

All participants were asked to report their physical activity over a usual week. The patient-reported total time in hours spent on a physical activity of intense or moderate intensity was recorded and if a participant did not spend 30 or more minutes on an uninterrupted intense or moderate physical activity, the value of zero was recorded.

\section{Retinal vessels analysis}

AnFF450 retinal camera (Zeiss AG, Jena, Germany) was used for static vessel analysis (SVA), and $30^{\circ}$ retinal photographs of each eye were obtained and analyzed with VISUALIS and VesselMap Software (Imedos Systems Ltd, Jena, Germany) as described in another paper (13). Standard parameters for this evaluation included the following: 1) central retinal artery equivalent (CRAE) based on CRA diameter; 2) central retinal vein equivalent (CRVE) based on CRV diameter; and 3) the arterio-venous ratio (AVR) representing the CRAE/CRVE ratio.

A Dynamic Vessel Analyzer with flicker light stimulation (DVA; Imedos, Jena, Germany) was used for measurements of retinal vessel diameter. A detailed description of the study protocol was previously provided in other publications $(9,14,15)$. In general, only the major temporal arterial and venous segments approximately $1.5 \mathrm{~mm}$ long were evaluated. The measurements were located at 1-2 disc diameters from the optic disc. The selection criteria for vessel segment locations were as follows: 1) no crossing or bifurcation in the measured section; 2) a curvature not exceeding $30^{\circ} ; 3$ ) a distance from neighboring vessels $>$ one vessel diameter; and 4) sufficient contrast with the surrounding eye fundus. Only one artery and one vein were measured in each eye. The standard program for DVA flicker stimulation was used during the study: three consecutive flicker cycles of $12.5-\mathrm{Hz}$ flicker frequency with 80-second observation time and a total duration of examination of $352 \mathrm{~s}$. The response was measured as the difference between the mean vascular diameter for the last 10 seconds of flicker stimulation and the mean vascular diameter for the 30 seconds directly preceding this stimulation divided by the latter value. The mean of the calculations for the three flicker cycles was used for statistical analysis of the response.

\section{Statistical analysis}

The between-group comparisons for the studied parameters were made using the Mann-Whitney test for quantitative variables and Fisher's exact test for qualitative variables. Given that the distribution of most quantitative variables were significantly different from a normal distribution (as assessed by the Shapiro-Wilk test), non-parametric tests were used. For vascular measures, the values from both eyes were averaged. The strength of the association between the quantitative variables was measured using Spearman's rank correlation coefficient (Rs). A multivariate analysis of independent factors associated with the change in flicker-induced diameter was performed using the 
general linear model (GLM). A $p<0.05$ was considered statistically significant.

\section{Results}

Table 1 provides the clinical characteristics of the patients from the study group and the age-matched controls. The mean duration of DM was $12.5+/-7.2$ years, and the mean $\mathrm{HbA1C}$ was $7+/-0.8 \%$. Twenty-two patients $(55 \%)$ were insulin-dependent. There were no significant differences in MAP, duration of arterial hypertension or smoking among the two groups. The BMI, VHR, weekly duration of physical activity and serum triglyceride levels were significantly increased, whereas HDL, LDL and total blood cholesterol levels were reduced in the DM group compared with controls.

The values of the retinal vessel parameters obtained for both groups are summarized in Table 2 .

The AVR obtained by static vessel analysis was similar in both groups.

The flicker-induced changes in the arterial diameter were significantly lower in the DM group compared with the controls $(\mathrm{p}<0.00026)$. The difference remained significant in the multivariate analysis performed in the GLM after adjustment for age and sex (the mean reduction in artery dilatation in the DM group was $1.12 \%, p=0.0016)$. Similarly, the venous response to flicker stimulation was also significantly decreased in diabetic patients compared with controls $(p=0.0095)$. The difference remained significant in the multivariate analysis performed in the GLM after adjustment for age and sex, (the mean reduction in vein dilatation in the DM group was $0.84 \%, p=0.062$ ). The results show that DM was an independent predictor of reduced flicker-induced vasodilation in the arterial and venous portion of retinal circulation. Figure 1 presents the representative retinal vascular responses to flickering light stimulation in patients with DM and healthy controls.

Notably, we did not identify a correlation between $\mathrm{HbA} 1 \mathrm{c}$ levels and vascular response to flicker stimulation. Similarly, no correlation was noted between flicker-induced vasodilation and TCH, HDL, LDL, or TG levels. We identified a positive correlation between the weekly duration of physical activity and improved arterial response to flicker light in the DM group (Rs $=+0.35, p=0.029$ ). Interestingly, positive correlations were noted between arterial and venous responses in both the DM group ( $R s=+0.54, p<0.00034)$ and the control group ( $R s=$ $+0.44, \mathrm{p}=0.0031$ ).

\begin{tabular}{|c|c|c|c|}
\hline Parameter & DM group & Control group & p value \\
\hline Number of subjects & 40 & 44 & - \\
\hline Sex (male / female) & $25 / 15$ & $37 / 7$ & 0.03 \\
\hline Age [years] (mean \pm SD) & $67.02 \pm 7.07$ & $67.68 \pm 5,53$ & 0.68 \\
\hline $\mathrm{TCH} \mathrm{mg} / \mathrm{dl}($ mean $\pm \mathrm{SD})$ & $183.1 \pm 40.5$ & $210.7 \pm 37.8$ & $<0.001$ \\
\hline $\mathrm{HDL} \mathrm{mg/dl} \mathrm{(mean} \pm$ SD) & $45,7 \pm 13.2$ & $61.6 \pm 12.4$ & $<0.001$ \\
\hline $\mathrm{LDL} \mathrm{mg} / \mathrm{dl}($ mean $\pm \mathrm{SD})$ & $100.1 \pm 34.0$ & $122.8 \pm 37.2$ & $<0.001$ \\
\hline $\mathrm{TG} \mathrm{mg} / \mathrm{dl}($ mean $\pm \mathrm{SD})$ & $145.3 \pm 50.6$ & $106.7 \pm 46.1$ & $<0.001$ \\
\hline BMI [kg/m2] (mean \pm SD) & $28.78 \pm 4,44$ & $26.7 \pm 3.35$ & 0.02 \\
\hline WHR (mean \pm SD) & $0.94 \pm 0.08$ & $0.87 \pm 0.07$ & $<0.001$ \\
\hline MAP [mmHg] (mean \pm SD) & $100.26 \pm 10.59$ & $99.55 \pm 9.22$ & 0.99 \\
\hline Current smokers (\%) & 7.5 & 4.55 & 0.66 \\
\hline Ex-smokers (\%) & 40 & 31.82 & 0.49 \\
\hline Smoking pack-years (mean \pm SD) & $12.28 \pm 23.6$ & $7.67 \pm 13.2$ & 0.49 \\
\hline Duration of arterial hypertension [years] (mean $\pm \mathrm{SD}$ ) & $11.62 \pm 9.51$ & $8.52 \pm 9.49$ & 0.08 \\
\hline Physical activity [hours] & $3.27 \pm 2.89$ & $2.04 \pm 2.11$ & 0.67 \\
\hline
\end{tabular}

Tab. I. Clinical characteristics of the study groups.

Tab. I. Charakterystyka kliniczna badanych grup pacjentów.

\begin{tabular}{|c|c|c|c|}
\hline Parameter & $\begin{array}{c}\text { DM group } \\
\text { Mean } \pm \text { SD }\end{array}$ & $\begin{array}{c}\text { Control group } \\
\text { Mean } \pm \text { SD }\end{array}$ & p value \\
\hline Arterial-to-venous ratio (AVR) & $0.85 \pm 0.04$ & $0.85 \pm 0.05$ & 0.85 \\
\hline Dynamic vessel analysis of arteries (DVAA) [\%] & $1.79 \pm 1.5$ & $2.86 \pm 1.5$ & $<0.001$ \\
\hline Dynamic vessel analysis of veins (DVAV) [\%] & $3.24 \pm 2.04$ & $4.07 \pm 1.83$ & 0.009 \\
\hline
\end{tabular}

Tab. 2. Retinal vascular parameters in the study groups.

Tab. 2. Parametry naczyń siatkówkowych w badanych grupach. 


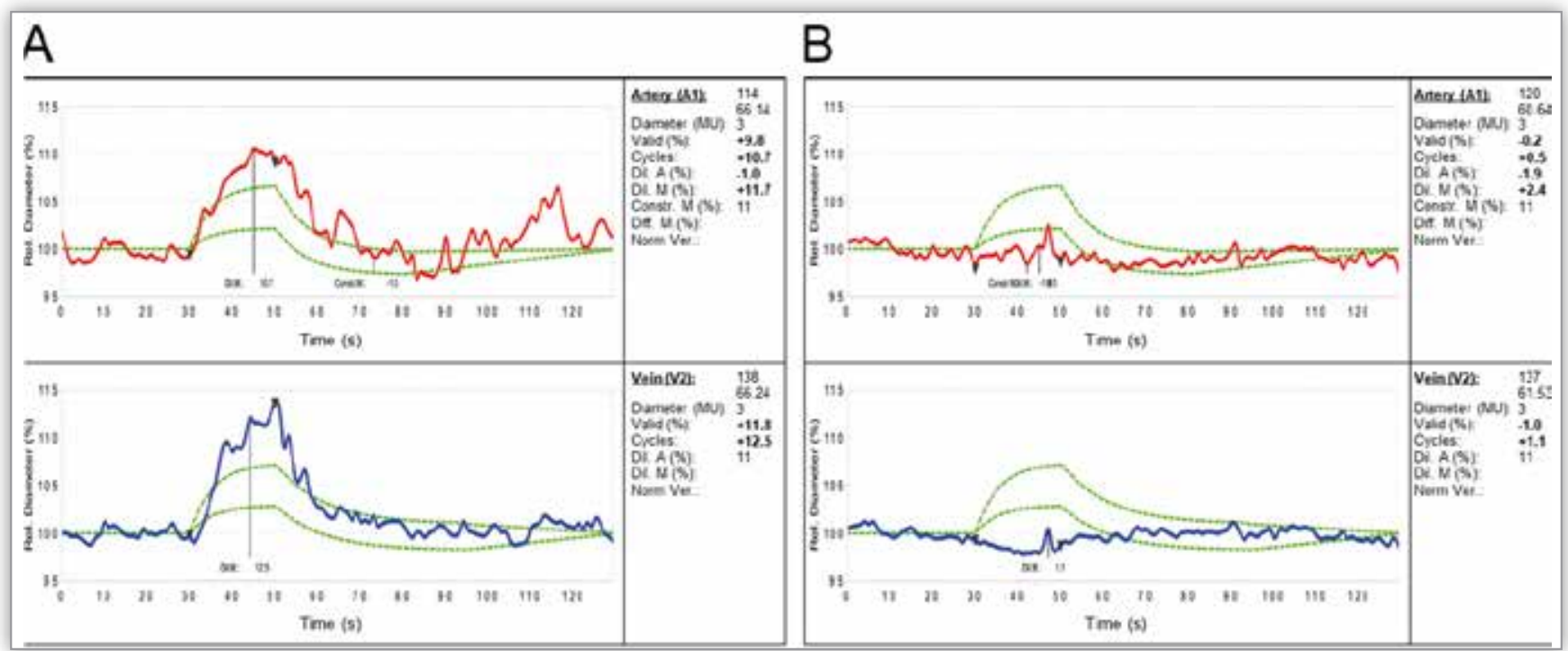

Fig. 1. Dynamic vessel analysis representative of a control $(A)$ and a diabetic subject $(B)$ expressed as the percentage change in arteriolar and vein diameters after flicker stimulation. Abbreviations: red curve - arteriole response, blue curve - vein response, dashed green line - normal distribution curve.

Ryc. 2. Przykład analizy dynamiki naczyniowej w grupie kontrolnej (A) i w grupie z cukrzycą (B) wyrażonej w postaci procentowej zmiany szerokości naczynia w reakcji na pobudzenie światlem (krzywa czerwona - odpowiedź naczyń tętniczych; krzywa niebieska -odpowiedź naczyń żylnych; obszar zielony - zakres odpowiedzi prawidłowej).

\section{Discussion}

Flicker light stimulation of the retina induces increased neural activity and leads to retinal and venous dilation due to the release of vasodilating factors from neural and endothelial cells. Evidence suggests that even the early stages of diabetic retinopathy are associated with abnormal retinal autoregulation probably due to endothelial cell dysfunction (16).

$\mathrm{NO}$ is one of the most important endothelium-derived vasodilators, and its bioavailability is reduced in diabetic patients. Given that flicker-light-induced vasodilation is mediated by NO, the DVA test may be used to estimate the capacity of endothelial cells to release NO in response to a physiological stimulus $(5,6)$. However, other factors may play a role in the altered vasoreactivity in prediabetic and diabetic patients. Impaired vasomotor responses observed in subjects with prediabetes and diabetes could result from impaired signaling between neurosensory retina and vessels. These impaired neurosensory coupling mechanisms may include glial cell or retinal barrier dysfunction and altered vascular endothelial growth factor signaling pathways (17). Neurodegeneration may also be an early stage in DR pathogenesis (4). In diabetic patients with no clinically detectable signs of DR, thinning of the photoreceptor, ganglion cell and nerve fiber layers was observed (18-20).

The study aimed to correlate retinal function with vascular response to flicker light in normotensive patients with diabetes and no diabetic retinopathy. This study demonstrated that in patients with diabetes, the onset of clinically detectable DR is preceded by both neural and neurovascular dysfunction. Electroretinogram pattern responses, oscillatory potential responses and vascular response to flicker light were significantly impaired in diabetic patients compared with controls (11). In type 1 diabetic patients, impaired DVA responses occurred even before evident ERG pattern abnormalities (7).

We investigated the response of retinal arteries and veins to flickering light in diabetic patients with no signs of diabetic re- tinopathy, and we found that the mean change in the flicker-induced retinal arterial diameter was significantly reduced in the DM group compared with the controls, but the AVR obtained by static vessel analysis was similar in both groups. This finding is consistent with other studies, demonstrating that dynamic vessel changes may precede detectable differences in static vessel measurements in diabetic patients without DR (21).

Given that other factors are associated with decreased flickering light responses, we adjusted our analysis for age and sex as covariates $(22,23,24,25)$. The results demonstrate that DM was an independent predictor of reduced flicker-induced vasodilation in the arterial and venous portion of retinal circulation.

Previous studies demonstrated that the retinal vessel flicker response is reduced in diabetic patients compared with controls as well as DM type I and DM type II, and the response decreases with more advanced stages of retinopathy. The venous response was reduced in patients without any visible signs of retinopathy indicating that blood flow autoregulation mechanisms are impaired before any structural damage to the retinal vessels can be detected $(16,22)$. A prospective cohort study in 276 subjects demonstrated that the responses of retinal arterioles and venules to flickering light are not only reduced in subjects with DR and decrease progressively with more severe stages of DR but that those reduced dilatory responses to flickering light are also associated with an increased likelihood of DR progression at 1 year in adult patients with diabetes. The incidence of DR at 1 year was 19 of 90 subjects (21.1\%). In a multivariate analysis adjusting for age, sex, smoking status, HbA1c, hypertension and hyperlipidemia, reduced arteriolar dilation was significantly associated with the onset of DR $(p=0.048)(26,27)$.

Furthermore, retinal arterial and venous reactivity was impaired in diabetic $(\mathrm{HbA} 1 \mathrm{c}>6.5 \%)$ and prediabetic $(\mathrm{HbA} 1 \mathrm{c} \geq 5.7$ and $<6.5 \%$ ) patients compared with healthy controls ( $\mathrm{HbA1c}$ $<5.7 \%$ ) (10). Prediabetes is associated with an increased risk 
of type 2 diabetes, endothelial dysfunction and cardiovascular risk developing later in life (28). Monitoring retinal reactivity can be an early marker of microvascular disease and endothelial dysfunction that can be followed up non-invasively. Although the variability in blood vessel caliber may affect the results, the DVA device is operator independent and was demonstrated to produce reproducible results (29.30). Our study showed a weak positive correlation between the duration of physical activity and better arterial response to flicker light in the DM group and may indicate that retinal vasoreactivity measurements can be a sensitive tool not only in to predict DR progression or monitor treatment response, but also to assess early vascular risk in diabetic patients.

\section{Conclusions}

Retinal vascular reactivity to flicker light stimulation is decreased in diabetic patients with no clinically detectable signs of diabetic retinopathy. DVA may be a valuable tool for early identification of patients at increased risk of diabetic retinopathy.

\section{References}

1. Nathan DM: The diabetes control and complications trial/ epidemiology of diabetes interventions and complications study at 30 years: overview. Diabetic Care 2014; 37: 9-16.

2. Nguyen TT, Alibrahim E, Islam FM, et al.: Inflammatory, haemostatic and other novel biomarkers for diabetic retinopathy: the multi-ethnic study of atherosclerosis. Diabetic Care 2009;32:1704-1709.

3. Cheung N, Mitchell P, Wong TY: Diabetic Retinopathy. Lancet 2010; 376:124-136.

4. Simo R, Hernandez C: Novel approaches for treating diabetic retinopathy based on recent pathogenic evidence. Prog Retin Eye Res. 2015; 48:160-180.

5. HinkU, Li H, Mollnau H, Oelze M, Matheis E, Hartmann M, et al.: Mechanisms underlying endothelial disfunction in diabetes mellitus. Cic Res 2001; 88: E14-22.

6. Dorner GT, Garhofer G, Kiss B, Polska E, Polak K, Riva CE, Schmetterer L: Nitric oxide regulates retinal vascular tone in humans. Am J Physiol 2003; 285: H631-636.

7. Lasta M, Pemp B, Schmidl D, et al.: Neurovascular dysfunction procedes neural disfunction in the retina of patients with type I diabetes. Invest Ophthalmol Vis Sci 2013; 54:842-847.

8. Garhofer G, Bek T, Boehm AG, et al. Use of the retinal vessel analyser in ocular blood flow research. Acta Ophthalmol 2010;88:717-22.

9. Liew G, Wang JJ, Mitchell P, Wong TY: Retinal vascular imaging: a new tool in microvascular disease research. Circ Cardiovasc Imaging 2008;1:156-161.

10. Lott MEJ, Slocomb JE, Shivkumar V, et al.: Impaired retinal vasodilator responses in prediabetes and type 2 diabets. Acta Ophthalmol 2013;91(6):462-469.

11. Lecleire-Collet A, Audo I, Aout M, et al.: Evaluation of Retinal Function and Flicker Light-Induced Retinal Vascular Response in Normotensive Patients with diabetes without Retinopathy. Invest Ophthalmol Vis Sci 2011; 52:2861-67.

12. X. World Medical Association. Declaration of. Helsinki. Ethical principles for medical research involving human subjects. Jama 2013;310:2191-94.
13. Hubbard LD, Brothers RJ, King WN, Clegg LX, Klein R, Cooper LS, et al:: Methods for evaluation of retinal microvascular abnormalities associated with hypertension/sclerosis in the atherosclerosis risk in communities study. Ophthalmology 1999;106:2269-80.

14. Bruckmann A, Seeliger C, Lehmann T, Schleussner E, Schlembach D: Altered retinal flicker response indicates microvascular disfunction in woman with preeclampsia Hypertension 2015;66:900-05.

15. Schuster AK, Fischer JE, Vossmerbaeumer C, Vossmerbaeumer U: Optical coherence tomography- based retinal vessel analysis for the evaluation of hypertensive vasculopathy. Acta Ophthalmol 2015;93:e148-153.

16. Grunewald JE, DuPont J, Riva CE: Retinal haemodynamic in patients with early diabetes mellitus. $\mathrm{Br} \mathrm{J}$ Ophthalmol 1996;80:327-331.

17. Pournaras CJ, Rungger-Brandle E, Riva CE, Hardarson SH, Stefansson E: Regulation of retinal blood flow in health and disease. Prog Retin Eye Res. 2008;27:284-330.

18. Van Dijk HW, Verbraak FD, Kok PH, et al.: Decreased retinal ganglion cell layer thickness in patients with type 1 diabetes. Invest Ophthalmol Vis Sci. 2010; 51:3660-3665.

19. Van Dijk HW, Verbraak FD, Kok PH, et al.: Early neurodegeneration in the retina of type 2 diabetic patients. Invest Ophthalmol Vis Sci.2012;53:2715-2719.

20. Tavares FJ, Alvez M, Dias-Santos A, et al.: Retinal neurodegeneration in diabetic patients without dibetic retinopathy. Invest Ophthalmol Vis Sci. 2016;57:6455-60.

21. Mandecka A, Dawczynski J, Blum M, et al.: Abnormal retinal autoregulation is detected by provoked stimulation with flicker light in well controlled patients with type 1 diabetes without retinopathy. Diabetes Res Clin Pract 2009;86:51-555).

22. Mandecka A, Dawczynski J, Blum M, Muller N, Kloos C, Wolf G, Vilser W, Hoyer $H$, Muller UA: Influence of flickering light on the retinal vessels in diabetic patients. Diabetes Care.2007;30:3048-3052.

23. Machalińska A, Pius-Sadowska E, Babiak K, Sałacka A, Safranow K, Kawa MP, Machaliński B: Correlation between flicker-induced retinal vessel vasodilation and plasma biomarkers of endothelial dysfunction in hypertensive patients. Current Eye Res 2017;00:1-7.

24. Kneser M, Kohlmann T, Pokorny J, Tost F: Age related decline of microvascular regulation measured in healthy individuals by retinal dynamic vessel analysis. Med Sci Monit 2009;15: 436-441 .

25. Kotiliar KE, LanzI IM, Schmidt-Trucksass A, Sitnikowa D, Ali M, Blume K, Halle M, Hanssen H: Dynamic retinal vessel response to flicker in obesity: a methodological approach. Microvasc Res 2011;81:123-128.

26. Lim LS, Ling LH, Ong PG, Foulds W, Tai ES, Wong E, Lee SY, Wong D, Cheung G, Wong TY: Dynamic Responses in Retinal Vessel Caliber With Flicker Light Stimulation in Eyes With Diabetic Retinopathy. Invest Ophthalmol Vis Sci 2014; 55: 5207$-5213$.

27. Lim LS, Ling LH, Ong PG, Foulds W, Tai ES, Wong TY: Dynamic responses in retinal Vessel Caliber with Flicker Light Stimulation and Risk of Diabetic Retinopathy and Its Progression. Invest Ophthalmol Vis Sci. 2017;58:2449-2455. 
28. Ford ES, Zhao G, Li C: Pre-diabetes and the risk for cardiovascular disease: a systematic revive of the evidence. J Am Coll Cardiol. 2010;55:1310-1317.

29. Polak K, Dorner G, Kiss B: Evaluation of the Zeiss retinal vessel analyser. Br J Ophthalmol 2000;84:1285-1290.
30. Sharfizad M, Witkowska KJ, Aschinger GC, et al.: Factors determining flicker-induced retinal vasodilation in healthy subjects. Invest Ophthalmol Vis Sci 2016;57:3306-3312.

The paper was originally received 13.11.2018 (KO-00188-2018)/ Praca wpłynęła do Redakcji 13.11.2018 (KO-00188-2018) Accepted for publication 11.03.2019/

Zakwalifikowano do druku 11.03.2019.

Reprint requests to (Adres do korespondencji):

Anna Machalińska MD, PhD

First Department of Ophthalmology

Al. Powstańców Wielkopolskich 72

70-111 Szczecin, Poland

tel: +4891 4838600

fax: +4891 4661347

e-mail: annam@pum.edu.pl

\section{Polskie Towarzystwo Okulistyczne www.pto.com.pl}

